\title{
The Mechanism of the Synergistic Anticancer Effect of CDDP and EPA in the TE1 Cell Line
}

\author{
AYAKO OGO ${ }^{1}$, SACHI MIYAKE ${ }^{1}$, HISAKO KUBOTA ${ }^{2}$, MASAHARU HIGASHIDA ${ }^{2}$, \\ HIDEO MATSUMOTO ${ }^{3}$, FUSAKO TERAMOTO ${ }^{1}$, TOSHIHIRO HIRAI ${ }^{3}$ and TOMIO UENO ${ }^{2}$ \\ ${ }^{1}$ Department of Clinical Nutrition, Faculty of Health Science and Technology, \\ Kawasaki University of Medical Science, Okayama, Japan; \\ ${ }^{2}$ Department of Digestive Surgery, Kawasaki Medical School, Okayama, Japan; \\ ${ }^{3}$ Mitsugi General Hospital, Hiroshima, Japan
}

\begin{abstract}
Background/Aim: Eicosapentaenoic acid (EPA) is an unsaturated fatty acid with various bioactivities, including antitumor effects. We previously reported a synergistic antitumor effect of cisplatin (CDDP) and EPA. Here, we examined the underlying mechanism. Materials and Methods: The human oesophageal cancer cell line TE-1 was treated with the combination of EPA and CDDP. Nuclear translocation of NF-kB, a transcription factor involved in cytokine production, was detected by immunohistochemistry. IL-6 levels were measured by ELISA. Apoptosis and cell cycle distribution were evaluated by flow cytometry. Results: Nuclear translocation of $N F-k B$ in TE-1 cells was synergistically decreased by CDDP and EPA. IL-6 production was increased following treatment with $C D D P$, but treatment with EPA decreased IL-6 levels. Apoptosis was synergistically induced by $C D D P$ and EPA. A $G_{2} / M$ cell cycle arrest was observed with the combination of CDDP and $150 \mu M E P A$, and $S$ phase arrest with the combination of CDDP and $100 \mu \mathrm{M}$ EPA. Conclusion: The combination of $C D D P$ and EPA synergistically suppresses $N F-\kappa B$ nuclear translocation and increases apoptosis by inducing cell cycle arrest at the $S$ or $G_{2} / M$ phase.
\end{abstract}

Eicosapentaenoic acid (EPA) is a polyunsaturated fatty acid that is abundant in fish oil and exhibits platelet aggregation inhibitory activity (1). EPA is effective in improving lipid metabolism, blood clotting and glucose metabolism

This article is freely accessible online.

Correspondence to: Ayako Ogo, Department of Clinical Nutrition, Faculty of Health Science and Technology, Kawasaki University of Medical Science, Matsushima 577, Kurashiki, Okayama 701-1111, Japan. Tel: +81 864621111, e-mail: ayako-ogo@med.kawasaki-m.ac.jp

Key Words: Eicosapentaenoic acid, cisplatin, IL-6, apoptosis. abnormality (1-5). Recent studies showed that EPA has cytostatic or apoptosis induction activity against various types of cancer cells (6-8). Another report using a mouse model revealed that EPA has antitumor activity (9). Furthermore, other studies reported anti-inflammatory action or possibility of weight gain from improved metabolism in cancer patients treated with EPA (10-12). Together these findings suggest that EPA might be useful in cancer treatment.

In our previous study, we reported several effects of EPA on the TE-1 human oesophageal cancer cell line (13). Lipopolysaccharide promotes the nuclear translocation of the NF-KB transcription factor (14). Lipopolysaccharide induces cytokine production in TE-1 cells, and this activity was inhibited by EPA (13). We further found that EPA promoted apoptosis and controlled tumor proliferation through inhibition of NF-kB nuclear translocation and activation. Several studies examined the combined use of EPA and anticancer agents and found that EPA showed a synergistic antitumor effect when combined with docetaxel, paclitaxel or cisplatin (CDDP) (15).

To clarify the mechanism of the synergistic antitumor effect of the combined use of EPA and CDDP, we examined the role of NF-KB and investigated cytokine production, apoptosis and cell cycle arrest in response to the combination treatment.

\section{Materials and Methods}

Cell lines, cell culture and reagents. The TE-1 cell line, which is derived from human oesophageal cancer, was purchased from RIKEN (Saitama, Japan). Cells were cultured in RPMI-1640 medium (Sigma-Aldrich, St Louis, MO, USA) containing 10\% foetal bovine serum (FBS), 100 units/ml penicillin and $100 \mu \mathrm{g} / \mathrm{ml}$ of streptomycin (Sigma-Aldrich) at $37^{\circ} \mathrm{C}$ and $5 \% \mathrm{CO}_{2}$.

EPA (cis-5,8,11,14,17-eicosapentaenoic acid sodium salt) (Sigma-Aldrich) was dissolved in PBS. A cisplatinum injection solution (Nichi-Iko Pharmaceutical, Toyama, Japan) was used for experiments with CDDP. 
Setting of EPA and CDDP concentration. Our previous studies examining the antitumor effect of EPA on TE-1 cells showed that the $\mathrm{IC}_{50}$ was $260 \mu \mathrm{M}$ (13). Based on this result, the EPA concentrations used in experiments in the current study were set to $0,100,150$ and $200 \mu \mathrm{M}$, as these concentrations did not result in any antitumor effect when EPA was applied alone. The blood concentration of CDDP ranged from 3.76 to $1.69 \mu \mathrm{g} / \mathrm{ml}$ when CDDP administered to patients (16), and therefore, CDDP was used at 0,2 and $5 \mu \mathrm{g} / \mathrm{ml}$ in this study.

Immunohistochemistry (IHC) for $N F-k B$. TE-1 cells were trypsinized, resuspended at $1 \times 10^{5}$ cells $/ \mathrm{ml}$ culture medium, and plated at $4 \times 10^{4}$ cells/well (400 $\mu \mathrm{l} /$ well) in LAB-TEK 8-well plates (Thermo Fisher Scientific, Waltham, MA, USA). Cells were cultured for $24 \mathrm{~h}$ in the medium containing $0,100,200 \mu \mathrm{M}$ EPA, or $0,2 \mu \mathrm{g} / \mathrm{ml} \mathrm{CDDP}$, or both. Then, cells were washed with PBS and fixed in Citesetter (Matsunami Garasu, Osaka, Japan). Cells were then incubated with NF-kB p65 (D14E12) XP ${ }^{\circledR}$ Rabbit mAb (Cell Signaling Technology, Danvers, MA, USA) as a primary antibody overnight at $4^{\circ} \mathrm{C}$. On the following day, cells were incubated with a colour coupler using the Dako REAL $^{\mathrm{TM}}$ EnVision ${ }^{\mathrm{TM}}$ Detection System, Peroxidase/DAB+, and Rabbit/Mouse (Agilent, Santa Clara, CA, USA) secondary antibody (13). Nuclei were stained with Mayer haematoxylin (Muto Kagaku, Tokyo, Japan) for $1 \mathrm{~min}$. Cells were examined and photographed using an IX83 microscope (Olympus, Tokyo, Japan). Five hundred cells were analyzed in one field, and cells with NF-kB-positive nuclear staining were counted. This experiment was repeated three times.

ELISA. TE-1 cells were trypsinized, resuspended at $1 \times 10^{5}$ cells $/ \mathrm{ml}$ in culture medium, and plated at $5 \times 10^{4}$ cells/well $(500 \mu \mathrm{l} /$ well $)$ in 24 -well plates. Cells were cultured for $24 \mathrm{~h}$ and then cultured in medium containing 0, 100 and $200 \mu \mathrm{M}$ EPA, or $0,2 \mu \mathrm{g} / \mathrm{ml}$ CDDP, or both. After $48 \mathrm{~h}$ of culture, the supernatant was collected and IL-6 levels were measured using an IL-6 human ELISA Kit (Thermo Fisher Scientific), according to the manufacturer's protocol. The measurement was performed using Varioskan Flash spectral scanning multimode reader (Thermo Fisher Scientific). This experiment was repeated three times.

Flow cytometry. To evaluate apoptosis, TE-1 cells were resuspended at $1 \times 10^{6} \mathrm{cells} / \mathrm{ml}$ and plated at $2 \times 10^{6}$ cells/well $(2 \mathrm{ml} / \mathrm{well})$ in $6-$ well plates. Cells were cultured for $24 \mathrm{~h}$ and then incubated in medium containing $0,100,150 \mu \mathrm{M}$ of EPA, or $0,2 \mu \mathrm{g} / \mathrm{ml}$ of CDDP, or both. Cells were collected $24 \mathrm{~h}$ later and stained using the Zombie Green ${ }^{\mathrm{TM}}$ Fixable Viability Kit (BioLegend, San Diego, CA, USA) and Annexin V, Alexa Fluor ${ }^{\text {TM }} 647$ conjugate (Thermo Fisher Scientific). Cells were analysed using the FACSAria III Cell Sorter, DIVA soft (Becton, Dickinson and Company, Franklin Lakes, NJ, USA), and data were examined using FlowJo ver.10 (Becton, Dickinson and Company). The experiment was repeated three times.

For cell cycle analyses, TE- 1 cells were resuspended at $1 \times 10^{6}$ cells $/ \mathrm{ml}$ and plated at $2 \times 10^{6}$ cells/well $(2 \mathrm{ml} /$ well $)$ in 6 -well plates. They were cultured for $24 \mathrm{~h}$ and then incubated in medium containing $0,100,150 \mu \mathrm{M}$ of EPA, or $0,2 \mu \mathrm{g} / \mathrm{ml}$ of CDDP, or both. Cells were collected $48 \mathrm{~h}$ later and stained with PI after RNase processing. Cells were analysed using the FACSAriaIII Cell Sorter, DIVA Soft (Becton, Dickinson and Company) and data were examined with FlowJo ver.10. The experiment was repeated three times.

Statistical analysis. Effects were considered as synergistic when the effect of the combined treatment was higher than the sum of the effects with EPA alone and CDDP alone.
Two-way factorial analysis was performed using JMP ver.1.2 and $t$-test was conducted for comparison of two groups. $p$-Value $<0.05$ was considered to indicate a significant difference.

\section{Results}

Intra-nuclear localization rate of $N F-k B$. Representative staining of NF-kB intra-nuclear localization in TE-1 cells treated with EPA, CDDP or their combination is shown in Figure 1A.

The rate of NF-kB nuclear stained cells in TE-1 cells treated with 0,2 and $5 \mu \mathrm{g} / \mathrm{ml}$ of CDDP was $8.2 \%, 9.5 \%$ and $8.4 \%$, respectively, and there were no significant differences between these rates. In contrast, treatment with 100 and 200 $\mu \mathrm{M}$ EPA resulted in $7.5 \%$ and $1.3 \% \mathrm{NF}-\mathrm{kB}$ nuclear stained cells, respectively, with a significant difference in cells treated with $200 \mu \mathrm{M}$ EPA compared with controls $(p<0.05)$. In cells treated with various concentrations of CDDP together with $100 \mu \mathrm{M}$ EPA, the rate of intranuclear localization of NF-kB was changed in a CDDP concentration-dependent tendency, without a significant difference.

In untreated cells, the percentage of cells with NF-kB intranuclear localization was $8.2 \%$. In cells treated with $100 \mu \mathrm{M}$ EPA alone, the percentage was $7.5 \%$ and in cells treated with $5 \mu \mathrm{g} / \mathrm{ml}$ of CDDP alone, the percentage was $8.4 \%$. Thus, the NF-kB intra-nuclear localization rate decreased by $0.7 \%$ in cells treated with $100 \mu \mathrm{M}$ EPA alone and increased by $0.2 \%$ in cells treated with $5 \mu \mathrm{g} / \mathrm{ml}$ CDDP alone compared with controls, although the difference was not significant. In comparison, the NF-kB intra-nuclear localization rate was $3 \%$ with the combination of $100 \mu \mathrm{M}$ EPA and $5 \mu \mathrm{g} / \mathrm{ml}$ CDDP. Because the additive effect was a $0.5 \%$ decrease, the reduction of NF-kB intra-nuclear localization rate to $3 \%$ indicated a synergic effect of the combination treatment. In response to $200 \mu \mathrm{M}$ EPA, NF-kB intra-nuclear localization was potently inhibited by only EPA alone and thus we were not able to calculate the combined effect with CDDP (Figure 1B).

IL-6 levels in culture supernatant. We next examined IL-6 levels in the culture supernatant (Figure 2). In control cells, the IL-6 levels in the culture supernatant were $247.6 \mathrm{pg} / \mathrm{ml}$. The levels of IL-6 increased to $384.2 \mathrm{pg} / \mathrm{ml}$ and $326.2 \mathrm{pg} / \mathrm{ml}$ with $2 \mu \mathrm{g} / \mathrm{ml}$ and $5 \mu \mathrm{g} / \mathrm{ml}$ of CDDP, respectively, whereas it decreased to $133.4 \mathrm{pg} / \mathrm{ml}$ and $136.1 \mathrm{pg} / \mathrm{ml}$ with $100 \mu \mathrm{M}$ and $200 \mu \mathrm{M}$ EPA, respectively.

When EPA was added together with CDDP, IL-6 levels were reduced. While cells treated with $2 \mu \mathrm{g} / \mathrm{ml}$ CDDP alone showed $384.2 \mathrm{pg} / \mathrm{ml}$ IL-6 levels, the concentrations were reduced to $212.6 \mathrm{pg} / \mathrm{ml}$ and $197.5 \mathrm{pg} / \mathrm{ml}$ with the addition of $100 \mu \mathrm{M}$ and $200 \mu \mathrm{M}$ EPA, respectively. While cells treated with $5 \mu \mathrm{g} / \mathrm{ml}$ CDDP alone showed $326.2 \mathrm{pg} / \mathrm{ml}$ IL-6 levels, the concentrations were reduced to $266.0 \mathrm{pg} / \mathrm{ml}$ and 164.1 $\mathrm{pg} / \mathrm{ml}$ with $100 \mu \mathrm{M}$ and $200 \mu \mathrm{M}$ EPA, respectively. Because 


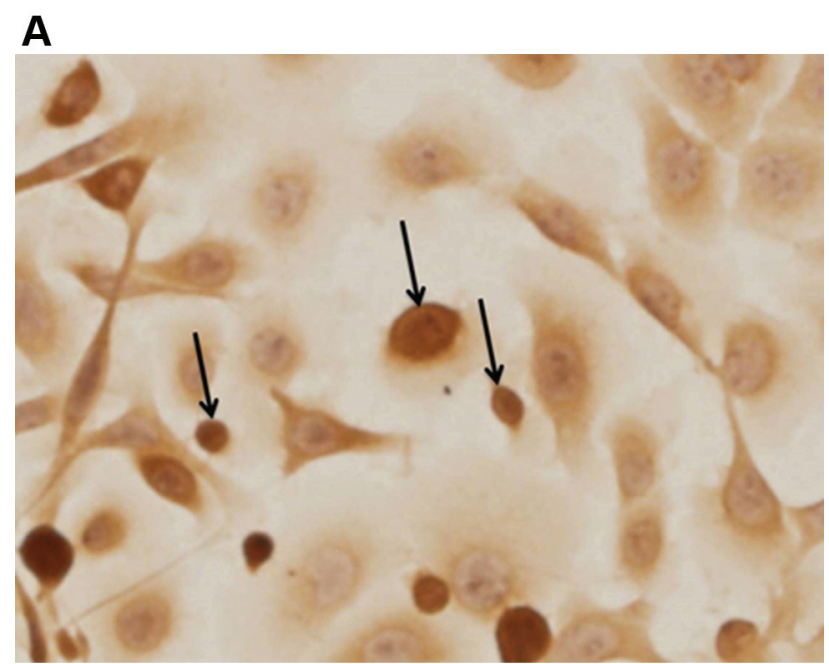

B

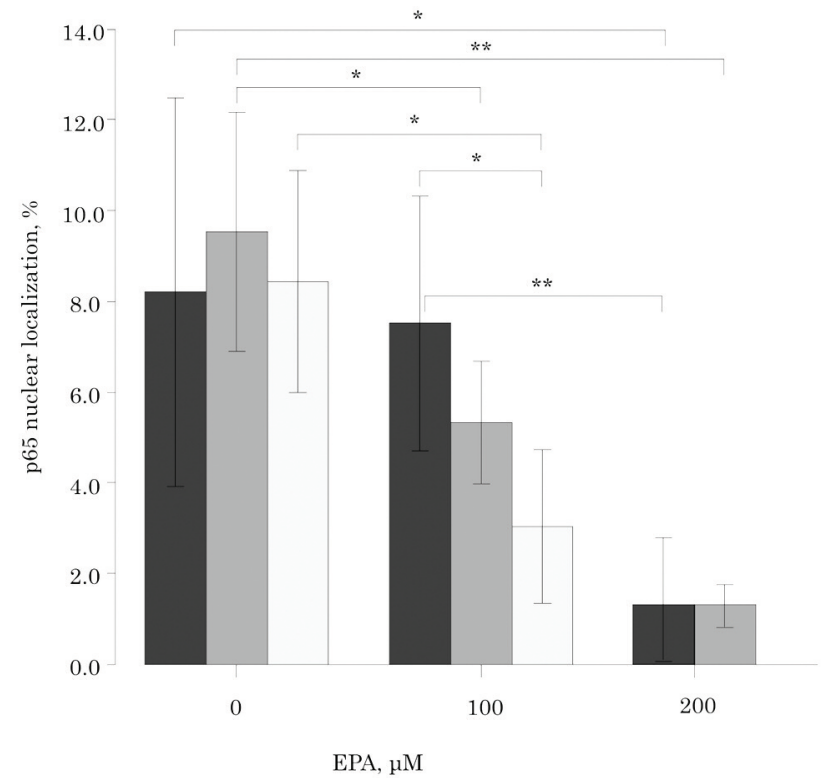

Figure 1. NF- $k B$ p65 nuclear localization and activation in TE-1 cells. (A) NF-kB nuclear localization in TE-1 cells. Black arrows indicate cells with nuclear $N F-k B$ p65 staining. (B) $N F-k B$ nuclear localization rates in TE-1 cells treated with EPA combined with CDDP for $24 \mathrm{~h}$. $(n=3)$. *p $<0.05$, **p $<0.01$.

IL-6 production was increased with CDDP alone, we were not able to evaluate an additional or synergic effect with the combination treatment.

Apoptosis. We next examined the levels of apoptosis in TE- 1 cells exposed to the single or combined treatments for $24 \mathrm{~h}$ (Figure 3). The apoptosis rates were as follows: $0 \mu \mathrm{M}$ EPA/0 $\mu \mathrm{g} / \mathrm{ml}$ CDDP: $6.7 \%$ (Figure 3A); $100 \mu \mathrm{M} \mathrm{EPA} / 0$ $\mu \mathrm{g} / \mathrm{ml}$ CDDP: $10.1 \%$ (Figure 3B), $150 \mu \mathrm{M}$ EPA $/ 0 \mu \mathrm{g} / \mathrm{ml}$

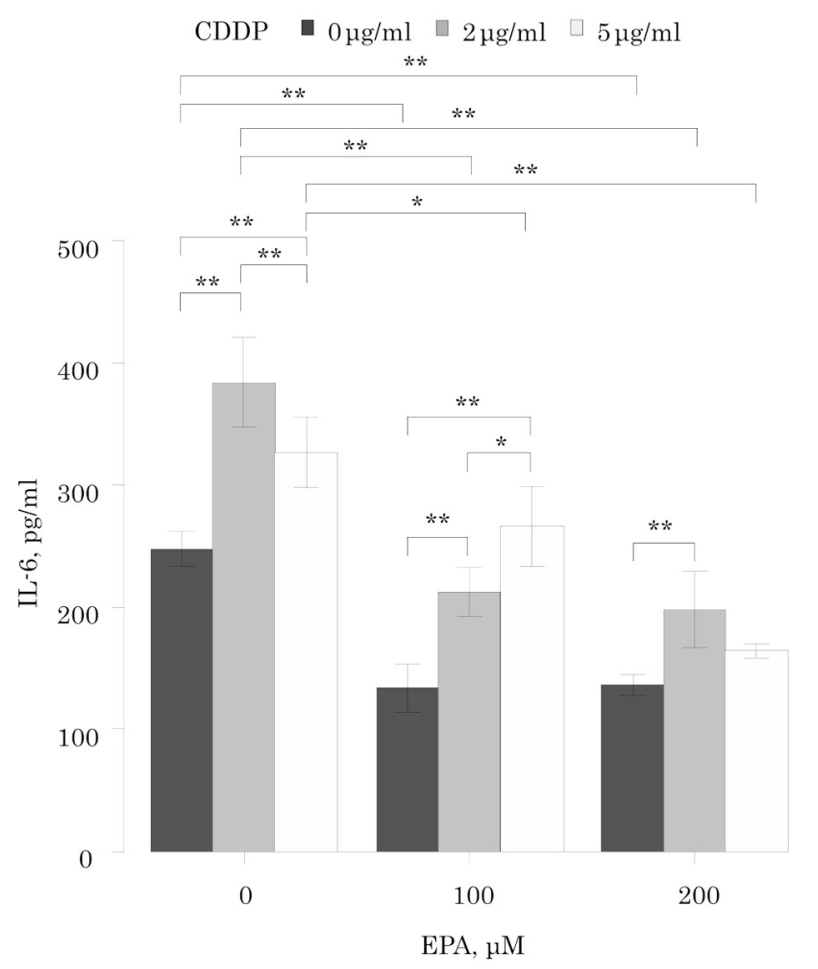

Figure 2. IL-6 levels in culture supernatant in TE-1 cells treated with EPA combined with CDDP for $48 h$. ${ }^{*} p<0.05$, **p<0.01 (n=3).

CDDP: $11.1 \%$ (Figure 3C); $0 \mu \mathrm{M}$ EPA $/ 2 \mu \mathrm{g} / \mathrm{ml}$ CDDP: $12.3 \%$ (Figure 3D); $100 \mu \mathrm{M}$ EPA/2 $\mu \mathrm{g} / \mathrm{ml}$ CDDP: $19.9 \%$ (Figure 3E), and $150 \mu \mathrm{M}$ EPA/2 $\mu \mathrm{g} / \mathrm{ml}$ CDDP: $22.8 \%$ (Figure 3F).

These results showed that apoptosis increased by $3.4 \%$ and $4.4 \%$ in cells treated with $100 \mu \mathrm{M}$ and $150 \mu \mathrm{M}$ EPA, respectively, compared with controls, without a significant difference. In contrast, apoptosis increased by $5.6 \%$ in response to $2 \mu \mathrm{g} / \mathrm{ml} \mathrm{CDDP}$, which was statistically significant. Notably, the combination of EPA together with 2 $\mu \mathrm{g} / \mathrm{ml}$ CDDP increased apoptosis to $19.9 \%$ and $22.8 \%$ in the presence of $100 \mu \mathrm{M}$ and $150 \mu \mathrm{M}$ EPA, respectively. These results indicate a synergistic effect of EPA combined with CDDP on apoptosis (Figure 3G).

Cell cycle analysis. We next examined the cell cycle distribution of TE- 1 cells exposed to the single or combined treatments for $48 \mathrm{~h}$ (Figure 4). In TE-1 cells incubated with $2 \mu \mathrm{g} / \mathrm{ml} \mathrm{CDDP}$ alone for $48 \mathrm{~h}$, the number of $\mathrm{G}_{0} / \mathrm{G}_{1}$ phase cells decreased $40.7 \%$, while the number of $S$ and $G_{2} / M$ phase cells increased $34.4 \%$ and $8.1 \%$, respectively $(p<0.01)$. No changes were observed in the cell cycle distribution of TE-1 cells exposed to EPA alone. In cells treated with $2 \mu \mathrm{g} / \mathrm{ml}$ CDDP combined with $100 \mu \mathrm{M}$ EPA 

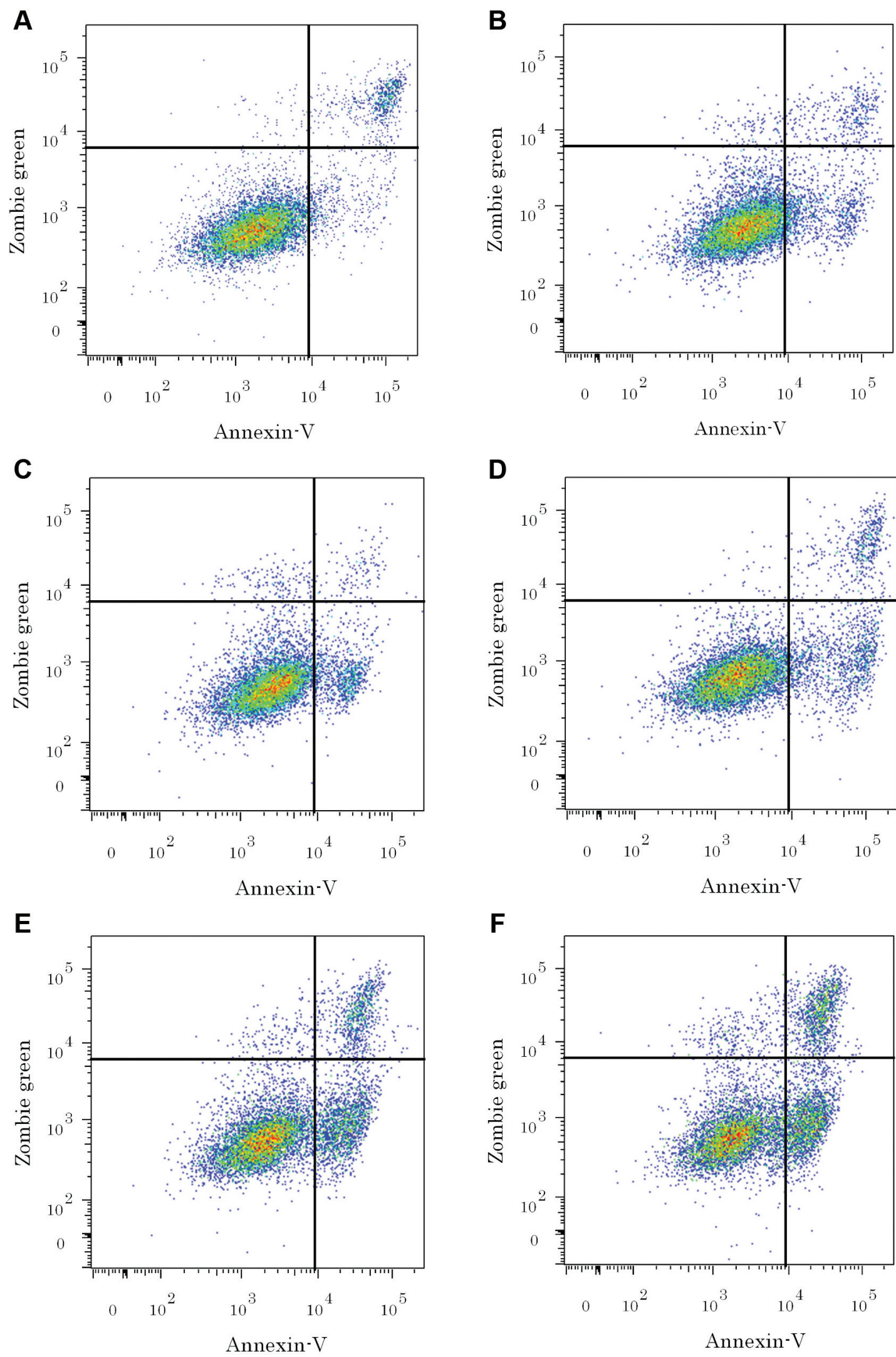

Figure 3. Continued 


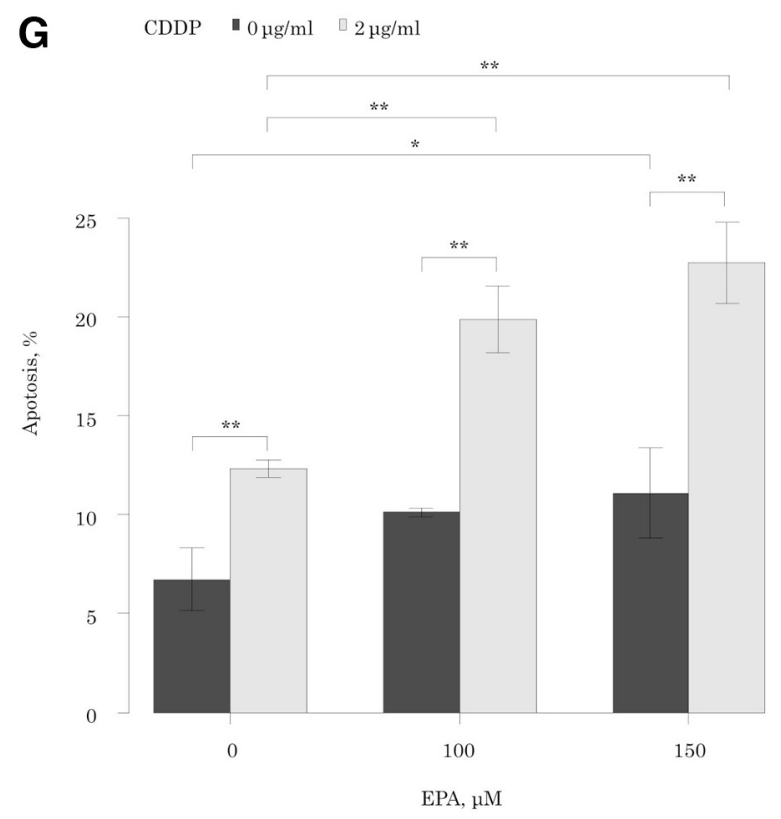

Figure 3. Apoptosis of TE-1 cells treated with EPA combined with $C D D P$ for $24 \mathrm{~h}$. (A) EPA $0 \mu \mathrm{M} / C D D P 0 \mu \mathrm{g} / \mathrm{ml}$, (B) EPA $100 \mu \mathrm{M} / \mathrm{CDDP}$ $0 \mu \mathrm{g} / \mathrm{ml}$, (C) EPA $150 \mu \mathrm{M} / C D D P O \mu \mathrm{g} / \mathrm{ml}$, (D) EPA $0 \mu \mathrm{M} / C D D P 2$ $\mu \mathrm{g} / \mathrm{ml}$, (E) EPA $100 \mu \mathrm{M} / C D D P 2 \mu \mathrm{g} / \mathrm{ml}$, (F) EPA $150 \mu \mathrm{M} / C D D P 2$ $\mu \mathrm{g} / \mathrm{ml} .(G)$ The percentages of apoptotic cells in the indicated treatment groups. $* p<0.05, * * p<0.01(n=3)$.

showed an $8.2 \%$ increase in the number of $\mathrm{S}$ phase cells $(p<0.01)$ and $5.0 \%$ decrease of $\mathrm{G}_{2} / \mathrm{M}$ phase cells $(p<0.01)$. In cells co-treated with $150 \mu \mathrm{M}$ EPA, the $\mathrm{S}$ phase population decreased $5.1 \%(p<0.05)$ and the $\mathrm{G}_{2} / \mathrm{M}$ phase population increased $10 \%(p<0.01)$.

\section{Discussion}

Carcinoma of the oesophagus is more prevalent in Japan than in western countries, and most oesophageal cancers are squamous cell carcinoma (17). Oesophageal cancer often develops in patients over 60 years old, and these patients represent approximately $70 \%$ of oesophageal cancer patients (18). In Japan, the percentage of the population over 65 years of age was $27.7 \%$ in 2017 , and it is expected to increase to $35.3 \%$ in 2040 (19). Therefore, as the older population continues to increase, the percentage of patients with carcinoma of the oesophagus is also expected to rise. Older patients are often diagnosed with various diseases, which can be accompanied by a risk for surgical management. In cases in which surgical treatment is not an option, chemoradiotherapy might be selected. However, chemoradiotherapy is associated with multiple side effects. Therefore, as a method to reinforce the effect without increasing the harmful effects of chemo-radiotherapy, the co- administration of polyunsaturated fatty acids (PUFAs) such as EPA is considered. Thus, we explored the potential effects of EPA on CDDP efficacy.

EPA is an n-3 PUFA that shows various bioactivities with minimum side effects. We previously reported that EPA regulated NF-kB nuclear localization, and therefore activation, and induced apoptosis in TE-1 cells (13). While the mechanism has not been fully elucidated, previous studies in gastric or colon cancer cell lines have suggested the involvement of activation of caspase-3, -7 and -9 or poly (ADP-ribose) polymerase (20) along with nuclear receptors including constitutive androstane receptor or pregnane $\mathrm{X}$ receptor (21).

A previous review reported that PUFAs enhanced the effect of 15 kinds of anticancer agents in various cancers (22). The tumor types included breast cancer, prostate cancer, colon cancer, lung cancer, cervical cancer, ovarian cancer, neuroblastoma, leukaemia and lymphoma. One study showed a high synergic effect of PUFAs on the survival of MDAMB-231 breast cancer cells, which are highly metastatic, when DHA was used together with paclitaxel or docetaxel (23). We also examined the combined effect of EPA together with four antitumor agents (paclitaxel, docetaxel, 5-FU, CDDP) on TE-1 cells and found that paclitaxel, docetaxel and CDDP showed a synergistic antitumor effect with EPA in a dose-dependent manner (15). However, the mechanism underlying this effect was not determined.

To examine the mechanism of the synergistic effect of EPA and CDDP, we focused on NF-kB, as it is a key protein in cell proliferation. Activation of $\mathrm{NF}-\mathrm{KB}$ affects production of cytokines such as IL-6, apoptosis and the cell cycle. NF$\mathrm{kB}$ is present in the cytoplasm in an inactivated state and undergoes nuclear localization and activation in response to cytotoxic signals or TNF $\alpha$ stimulation. We reported that EPA induced NF-kB activation in TE- 1 cells (13). Another study showed that CDDP regulated NF-kB activation (23). Therefore, we examined whether NF-kB activation was synergistically enhanced in response to the combination of CDDP and EPA. To evaluate the potential synergistic effect of CDDP and EPA, the EPA concentration was set at a level that does not induce antitumor effects (13). Notably, our results showed that $\mathrm{NF}-\mathrm{kB}$ activation was suppressed synergistically with the combination of EPA with CDDP.

We further examined the anti-inflammatory effect of the combination treatment in TE1 cells. Because inflammatory cytokines, such as IL-6, promote tumor growth or metastasis, the control of cytokine production is important in tumor management (24). EPA alone suppressed IL-6 production, while CDDP alone increased IL-6 production. EPA together with CDDP further suppressed IL-6 in a concentrationdependent manner. Therefore, no synergistic effect was determined. A previous study reported that head and neck squamous cell carcinoma patients with high level of IL-6 


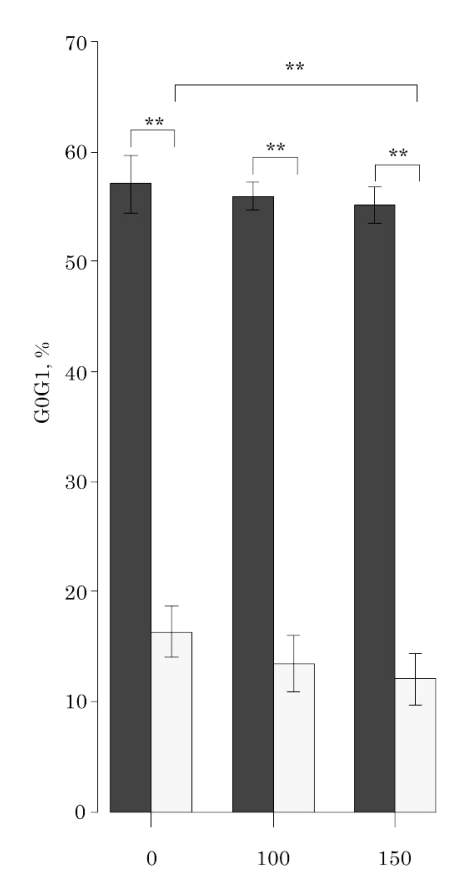

$\mathrm{CDDP} \quad \square \mu \mathrm{g} / \mathrm{ml} \quad \square 2 \mu \mathrm{g} / \mathrm{ml}$
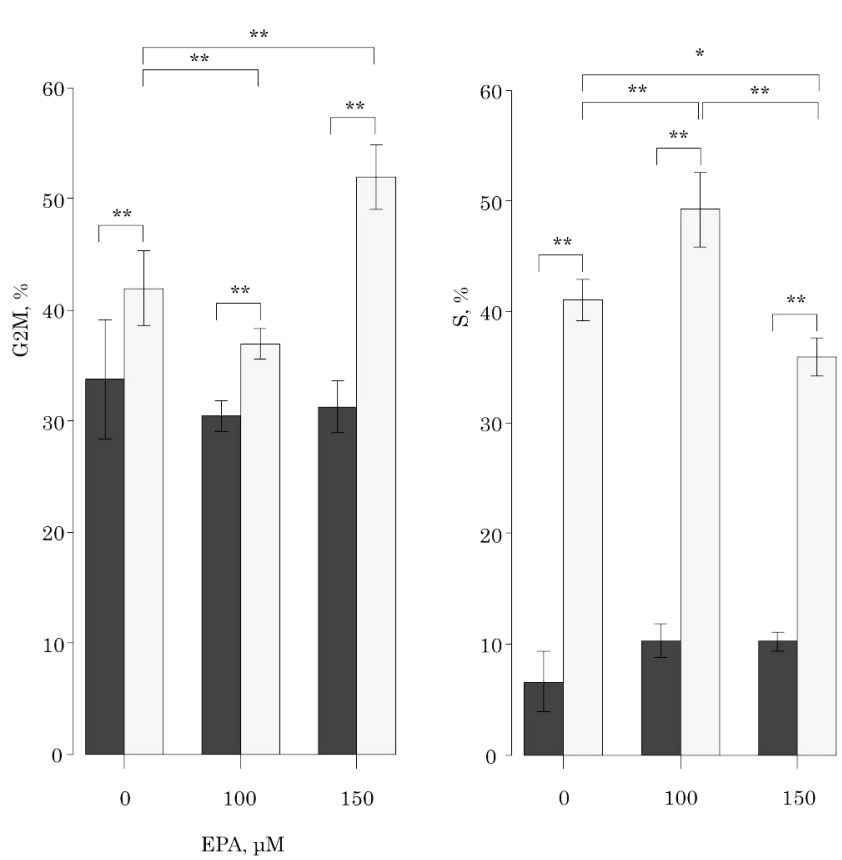

Figure 4. Cell cycle distributions of TE-1 cells treated with EPA combined with CDDP for 48 h. *p<0.05, **p<0.01 (n=3).

showed CDDP-resistance and poor prognosis (25). Therefore, EPA intake during therapy with CDDP might be useful from the viewpoint of prevention of CDDP resistance.

$\mathrm{NF}-\mathrm{kB}$ activation is related to apoptosis. We previously showed that EPA promoted apoptosis in TE-1 cells (13). Because the combined use of CDDP and EPA synergistically suppressed NF-kB, we further evaluated the effects of the combination treatment on apoptosis. Our results showed a $19.9 \%$ increase in cells treated with EPA $150 \mu \mathrm{M} / \mathrm{CDDP} 2 \mu \mathrm{g} / \mathrm{ml}$ and $22.8 \%$ increase in cells treated with EPA $100 \mu \mathrm{M} / \mathrm{CDDP} 2 \mu \mathrm{g} / \mathrm{ml}$. These results indicate that the increase in apoptosis in response to co-treatment of EPA and CDDP was synergistic.

The cell cycle is closely related with cell proliferation and apoptosis. Previous studies showed that inhibition of NF-kB activation suppresses the cell cycle (26-28). CDDP binds to DNA and stops DNA duplication. Therefore, we evaluated cell cycle changes in TE1 cells treated with the combination of CDDP and EPA. No alterations in the cell cycle were observed in response to EPA only. However, in cells treated with the combination of $2 \mu \mathrm{g} / \mathrm{ml} \mathrm{CDDP}$ and EPA, cells in S phase increased significantly (8.2\%) with EPA $100 \mu \mathrm{M}$, while cells in $\mathrm{G}_{2} / \mathrm{M}$ increased significantly (10\%) with EPA $150 \mu \mathrm{M}$, compared with CDDP alone. These results indicate an increase of apoptosis with the combined treatment; however, the difference in cell cycle phase distributions between the two EPA concentrations is not yet clear. In the human pancreatic cancer cell line MIA PaCa-2, EPA promoted apoptosis with an increase in the number of cells in the sub- $\mathrm{G}_{1}$ and $\mathrm{G}_{2} / \mathrm{M}$ phase (29). In the human breast cancer cell lines MCF-7 and MDA-MB-231, genistein increased apoptosis with a G2/M phase arrest, an increase in Bax and Caspase 3 and decrease in Bcl-XL (30). In addition, $\mathrm{a}_{2} / \mathrm{M}$ arrest and increase in apoptosis were reported with various drugs in human cancer cell lines such as colon cancer (31), prostate cancer $(32,33)$ and other cancer cells $(34)$, but the detailed mechanism was not identified. However, apoptosis-inducing drugs exert their effects by regulating proteins such as Bax, Bcl-xL, Bcl-2, Caspase3, Caspase8, cdc2 or cdk2 and causing $\mathrm{G}_{2} / \mathrm{M}$ arrest (31-33). In addition, DHA, an n-3 unsaturated fatty acid similar to EPA, regulates cell cycle-related proteins and induces a $\mathrm{G}_{2} / \mathrm{M}$ phase arrest as well as a $G_{1}$ arrest (34). Therefore, future studies are needed to more precisely clarify the mechanism by which the combination of CDDP and EPA exhibits a synergistic effect on apoptosis.

\section{Conclusion}

The combination of EPA and CDDP showed a synergic effect on NF-kB activation and cytostatic action in the TE-1 cell line and induced IL-6 production and cell cycle arrest. 


\section{Conflicts of Interest}

The Authors declare no conflicts of interest associated with this manuscript.

\section{Authors' Contributions}

Ayako Ogo: Investigation, Visualization, Writing. Sachi Miyake: Resources. Hisako Kubota: Supervision. Masaharu Higashida: Supervision. Hideo Matsumoto: Supervision. Fusako Teramoto: Supervision. Toshihiro Hirai: Conceptualization, Supervision, Writing, review \& editing. Tomio Ueno: Supervision, review \& editing.

\section{Acknowledgements}

This research study was conducted using Kawasaki Medical School's faculty research expenses. The Authors would like to thank Edanz Group (https://en-author-services.edanz.com/ac) for their English language editing services.

\section{References}

1 Wiktorowska-Owczarek A, Berezińska $\mathrm{M}$ and Nowak JZ: PUFAs: Structures, metabolism and functions. Adv Clin Exp Med 24(6): 931-941, 2015. PMID: 26771963. DOI: 10.17219/ acem $/ 31243$

2 Tanaka K, Ishikawa Y, Yokoyama M, Origasa H, Matsuzaki M, Saito Y, Matsuzawa Y, Sasaki J, Oikawa S, Hishida H, Itakura H, Kita T, Kitabatake A, Nakaya N, Sakata T, Shimada K, Shirato K and JELIS Investigators, Japan.: Reduction in the recurrence of stroke by eicosapentaenoic acid for hypercholesterolemic patients: Subanalysis of the JELIS trial. Stroke 39(7): 2052-2058, 2008. PMID: 18451347. DOI: 10.1161/STROKEAHA.107.509455

3 Koba S and Sasaki J: Treatment of hyperlipidemia from Japanese evidence. J Atheroscler Thromb 13(6): 267-280, 2006. PMID: 17192691. DOI: $10.5551 /$ jat.13.267

4 Borow KM, Nelson JR and Mason RP: Biologic plausibility, cellular effects, and molecular mechanisms of eicosapentaenoic acid (EPA) in atherosclerosis. Atherosclerosis 242(1): 357-366, 2015. PMID: 26253795. DOI: 10.1016/j.atherosclerosis.2015. 07.035

5 Oikawa S, Yokoyama M, Origasa H, Matsuzaki M, Matsuzawa Y, Saito Y, Ishikawa Y, Sasaki J, Hishida H, Itakura H, Kita T, Kitabatake A, Nakaya N, Sakata T, Shimada K, Shirato K and JELIS Investigators, Japan.: Suppressive effect of EPA on the incidence of coronary events in hypercholesterolemia with impaired glucose metabolism: Sub-analysis of the Japan EPA Lipid Intervention Study (JELIS). Atherosclerosis 206(2): 535-539, 2009. PMID: 19447387. DOI: 10.1016/j.atherosclerosis.2009.03.029

6 Shirota T, Haji S, Yamasaki M, Iwasaki T, Hidaka T, Takeyama Y, Shiozaki $\mathrm{H}$ and Ohyanagi H: Apoptosis in human pancreatic cancer cells induced by eicosapentaenoic acid. Nutrition 21(10): 10101017, 2005. PMID: 16157238. DOI: 10.1016/j.nut.2004.12.013

7 Noguchi M, Earashi M, Minami M, Kinoshita K and Miyazaki I: Effects of eicosapentaenoic and docosahexaenoic acid on cell growth and prostaglandin $\mathrm{E}$ and leukotriene $\mathrm{B}$ production by a human breast cancer cell line (MDA-MB-231). Oncology 52(6): 458-464, 1995. PMID: 7478431. DOI: 10.1159/000227511
8 Notarnicola M, Messa C, Refolo MG, Tutino V, Miccolis A and Caruso MG: Polyunsaturated fatty acids reduce fatty acid synthase and hydroxy-methyl-glutaryl CoA-reductase gene expression and promote apoptosis in HepG2 cell line. Lipids Health Dis 10: 10, 2011. PMID: 21244676. DOI: 10.1186/1476511X-10-10

9 Funahashi H, Satake M, Hasan S, Sawai H, Newman RA, Reber HA, Hines OJ and Eibl G: Opposing effects of n-6 and n-3 polyunsaturated fatty acids on pancreatic cancer growth. Pancreas 36(4): 353-362, 2008. PMID: 18437081. DOI: 10.1097/MPA.0b013e31815ccc44

10 Elia M, Van Bokhorst-de van der Schueren MA, Garvey J, Goedhart A, Lundholm K, Nitenberg G and Stratton RJ: Enteral (oral or tube administration) nutritional support and eicosapentaenoic acid in patients with cancer: A systematic review. Int J Oncol 28(1): 5-23, 2006. PMID: 16327975. DOI: 10.3892/ijo.28.1.5

11 Pappalardo G, Almeida A and Ravasco P: Eicosapentaenoic acid in cancer improves body composition and modulates metabolism. Nutrition 31(4): 549-555, 2015. PMID: 25770317. DOI: $10.1016 /$ j.nut.2014.12.002

12 Read JA, Beale PJ, Volker DH, Smith N, Childs A and Clarke SJ: Nutrition intervention using an eicosapentaenoic acid (EPA)containing supplement in patients with advanced colorectal cancer. Effects on nutritional and inflammatory status: A phase II trial. Support Care Cancer 15(3): 301-307, 2007. PMID: 17021855. DOI: $10.1007 / \mathrm{s} 00520-006-0153-3$

13 Kubota H, Matsumoto H, Higashida M, Murakami H, Nakashima H, Oka Y, Okumura H, Yamamura M, Nakamura M and Hirai T: Eicosapentaenoic acid modifies cytokine activity and inhibits cell proliferation in an oesophageal cancer cell line. Anticancer Res 33(10): 4319-4324, 2013. PMID: 24122998.

14 Hoesel B and Schmid JA: The complexity of NF-kB signaling in inflammation and cancer. Mol Cancer 12: 86, 2013. PMID: 23915189. DOI: 10.1186/1476-4598-12-86

15 Ogo A, Miyake S, Kubota H, Higashida M, Matsumoto H, Teramoto F and Hirai T: Synergistic effect of eicosapentaenoic acid on antiproliferative action of anticancer drugs in a cancer cell line model. Ann Nutr Metab 71(3-4): 247-252, 2017. PMID: 29136623. DOI: $10.1159 / 000484618$

16 Horiuchi M, Miyake H and Inuyama M: Pharmacokinetics of cisplatin. Otologia Fukuoka 30(2): 208-210, 1984. (In Japanese)

17 Sawada G, Niida A, Uchi R, Hirata H, Shimamura T, Suzuki Y, Shiraishi Y, Chiba K, Imoto S, Takahashi Y, Iwaya T, Sudo T, Hayashi T, Takai H, Kawasaki Y, Matsukawa T, Eguchi H, Sugimachi K, Tanaka F, Suzuki H, Yamamoto K, Ishii H, Shimizu M, Yamazaki H, Yamazaki M, Tachimori Y, Kajiyama Y, Natsugoe S, Fujita H, Mafune K, Tanaka Y, Kelsell DP, Scott CA, Tsuji S, Yachida S, Shibata T, Sugano S, Doki Y, Akiyama T, Aburatani H, Ogawa S, Miyano S, Mori M and Mimori K: Genomic landscape of esophageal squamous cell carcinoma in a Japanese population. Gastroenterology 150(5): 1171-1182, 2016. PMID: 26873401. DOI: 10.1053/j.gastro.2016.01.035

18 Cancer Information Services, National Cancer Center, Japan. The latest cancer statistics. Available at: https:/ganjoho.jp/ reg_stat/statistics/stat/summary.html [Last accessed on January 25, 2021]

19 Japan Ministry of Internal Affairs and Communications Statistics Bureau. Statistics Topics 2018. Available at: https://www.stat.go. jp/data/topics/topi1031.html [Last accessed on January 8, 2021] 
20 Mizoguchi K, Ishiguro H, Kimura M, Takahashi H, Sakamoto $\mathrm{N}$, Tanaka $\mathrm{T}$ and Takeyama $\mathrm{H}$ : Induction of apoptosis by eicosapentaenoic acid in esophageal squamous cell carcinoma. Anticancer Res 34(12): 7145-7149, 2014. PMID: 25503142.

21 Kuan CY, Walker TH, Luo PG and Chen CF: Long-chain polyunsaturated fatty acids promote paclitaxel cytotoxicity via inhibition of the MDR1 gene in the human colon cancer Caco-2 cell line. J Am Coll Nutr 30(4): 265-273, 2011. PMID: 21917707. DOI: 10.1080/07315724.2011.10719969

22 Hajjaji N and Bougnoux P: Selective sensitization of tumors to chemotherapy by marine-derived lipids: A review. Cancer Treat Rev 39(5): 473-488, 2013. PMID: 22850619. DOI: 10.1016/ j.ctrv.2012.07.001

23 Fang Y, Chai Z, Wang D, Kuang T, Wu W and Lou W: DNAPKcs deficiency sensitizes the human hepatoma HepG2 cells to cisplatin and 5-fluorouracil through suppression of the PI3K/Akt/NF-kB pathway. Mol Cell Biochem 399(1-2): 269278, 2015. PMID: 25348361. DOI: 10.1007/s11010-014-2253-6

24 Hirai T, Matsumoto H, Kubota H and Yamaguchi Y: Regulating surgical oncotaxis to improve the outcomes in cancer patients. Surg Today 44(5): 804-811, 2014. PMID: 23736890. DOI: $10.1007 / \mathrm{s} 00595-013-0627-0$

25 Gao J, Zhao S and Halstensen TS: Increased interleukin-6 expression is associated with poor prognosis and acquired cisplatin resistance in head and neck squamous cell carcinoma. Oncol Rep 35(6): 3265-3274, 2016. PMID: 27108527. DOI: 10.3892/or.2016.4765

26 Jin R, Chen Q, Yao S, Bai E, Fu W, Wang L, Wang J, Du X, Wei T, Xu H, Jiang C, Qiu P, Wu J, Li W and Liang G: Synthesis and anti-tumor activity of EF24 analogues as IKK $\beta$ inhibitors. Eur J Med Chem 144: 218-228, 2018. PMID: 29351887. DOI: 10.1016/j.ejmech.2017.11.077

27 Chen HH, Chen SP, Zheng QL, Nie SP, Li WJ, Hu XJ and Xie MY: Genistein promotes proliferation of human cervical cancer cells through estrogen receptor-mediated PI3K/Akt-NF-KB pathway. J Cancer 9(2): 288-295, 2018. PMID: 29344275. DOI: 10.7150/jca.20499
28 Allegra A, Speciale A, Molonia MS, Guglielmo L, Musolino C, Ferlazzo G, Costa G, Saija A and Cimino F: Curcumin ameliorates the in vitro efficacy of carfilzomib in human multiple myeloma U266 cells targeting p53 and NF-kB pathways. Toxicol In Vitro 47: 186-194, 2018. PMID: 29223572. DOI: 10.1016/j.tiv.2017.12.001

29 Lai PB, Ross JA, Fearon KC, Anderson JD and Carter DC: Cell cycle arrest and induction of apoptosis in pancreatic cancer cells exposed to eicosapentaenoic acid in vitro. Br J Cancer 74(9): 1375-1383, 1996. PMID: 8912532. DOI: 10.1038/bjc.1996.552

30 Nakagawa H, Yamamoto D, Kiyozuka Y, Tsuta K, Uemura Y, Hioki K, Tsutsui $\mathrm{Y}$ and Tsubura A: Effects of genistein and synergistic action in combination with eicosapentaenoic acid on the growth of breast cancer cell lines. J Cancer Res Clin Oncol 126(8): 448-454, 2000. PMID: 10961387.

31 Moragoda L, Jaszewski R and Majumdar AP: Curcumin induced modulation of cell cycle and apoptosis in gastric and colon cancer cells. Anticancer Res 21(2A): 873-878, 2001. PMID: 11396178

32 Nehmé A, Varadarajan P, Sellakumar G, Gerhold M, Niedner H, Zhang Q, Lin X and Christen RD: Modulation of docetaxelinduced apoptosis and cell cycle arrest by all- trans retinoic acid in prostate cancer cells. Br J Cancer 84(11): 1571-1576, 2001. PMID: 11384110. DOI: 10.1054/bjoc.2001.1818

33 Qadan LR, Perez-Stable CM, Anderson C, D'Ippolito G, Herron A, Howard GA and Roos BA: 2-Methoxyestradiol induces $\mathrm{G}_{2} / \mathrm{M}$ arrest and apoptosis in prostate cancer. Biochem Biophys Res Commun 285(5): 1259-1266, 2001. PMID: 11478793. DOI: 10.1006/bbrc. 2001.5320

34 Newell M, Baker K, Postovit LM and Field CJ: A critical review on the effect of Docosahexaenoic Acid (DHA) on cancer cell cycle progression. Int J Mol Sci 18(8): 2017. PMID: 28817068. DOI: $10.3390 /$ ijms 18081784

Received February 12, 2021

Revised February 26, 2021 Accepted March 1, 2021 